\title{
Teaching as Inquiry: Teachers Understanding and its Implication for Teaching and Learning
}

\author{
Isaac Buabeng ${ }^{1, *}$ \& Clara Akuamoah-Boateng ${ }^{2}$ \\ ${ }^{1}$ Department of Basic Education, University of Cape Coast, Ghana \\ ${ }^{2}$ College of Distance Education, University of Cape Coast, Ghana \\ *Correspondence: Department of Basic Education, University of Cape Coast, Ghana. E-mail: ibuabeng@ucc.edu.gh
}

Received: October 29, $2019 \quad$ Accepted: December 7, $2019 \quad$ Online Published: December 18, 2019

doi:10.5430/wje.v9n6p45

URL: https://doi.org/10.5430/wje.v9n6p45

\begin{abstract}
Teaching as inquiry (TAI) is described as a component of effective pedagogy that has significant impact on learning outcome. Based on this premises, the study sought to examine TAI and its implications for teaching and learning in the Cape Coast Metropolis, Ghana. The descriptive survey design was adopted for the study and a sample of 160 basic school teachers was selected from three circuits within the Cape Coast Metropolis. A questionnaire and an interview guide were used in collecting the data for the study. Data obtained from the questionnaire were analyzed using descriptive statistics (frequency count, percentages and means and standard deviations) whereas the interview data was transcribed and presented by doing thematic analysis. The study revealed that majority of the respondents had knowledge about TAI. In addition, the study showed that the teachers engaged in TAI practices such as reflecting and questioning their methods of teaching, identifying the academic needs of students before planning instruction and engaging in projects and research concerning the subject and content to be delivered. Findings from the study showed that teachers who participated in the study have embraced the concept of TAI very well and considering how they can mentor and lead others. It was recommended that the Cape Coast Metropolitan education office should organize intermittent workshops and training for teachers on TAI to help teachers build specific skills and refinements for reflection and action and planning strategies to support learners to learn specific things (content or skills) that teachers can specifically monitor in terms of student outcomes.
\end{abstract}

Keywords: teaching as inquiry, teaching practices; instructional methods, quality teaching and learning, students' outcomes

\section{Introduction}

This study is focused on promoting teachers learning about their practices through teaching as inquiry. Teaching as inquiry (TAI) is a powerful professional development noted for promoting teachers learning and enhancing student learning. Students' outcomes are improved if evidence of their achievement and its implications for teaching is examined. Studies have shown that teachers and their curriculum developers who worked together to examine the implications of evidence of student achievement for their teaching had higher achieving students (Timperly \& Wiseman, 2003; Timperly \& Parr, 2004). TAI has, at its core, the purpose of redressing inequality while simultaneously enhancing the quality of teaching and learning (Conner, 2015).

As indicated by Conner, (2015), TAI is an approach to teaching, but not anything extra that teachers are supposed to carry out. TAI supports teachers to be more effective in planning, teaching and reflective on what they do when implemented at part of the teaching and learning process. Besides, TAI is more of a mindset towards teaching where learners' needs are central and refinements to teaching are continuous (Conner). Teachers with this kind of mindset continue to search for refinements to their teaching practice and are hopeful with the fact that they will inevitably achieve an outcome in response to their efforts. TAI is about the teacher reflecting on what to do and then changing the practice - sometimes in a small way and sometimes much bigger. It sometimes simply means to address issues of participation, or engagement. The teacher may change his or her practice for a small group of students or may focus on the whole class.

In every society, education has importance for the growth and development of the society. It is an instrument of 
change which transforms the individuals in the society and ultimately transforms the society as a whole (Akhihiero, 2011). This is the reason why education is given the utmost attention in most societies (Jones, 2001). In schools, the target is to ensure that learning has taken place. However, this can happen when there is effective teaching. Effective teaching of any subject does not only stimulate the interest of students in the subject but also enhance students' overall outcome (Nwike \& Onyejegbu, 2013). This means teachers and their approaches to teaching are important in the school system. It has been found by several researchers such as Cuttance (2000) and Reynolds, Creemers, Stringfield, Teddlie, and Schafer (2002) that the difference in the quality of teaching is a major determinant of academic achievement than other school factors. The study of Cuttance as well as that of Reynolds et al. pointed to the fact that regardless of the conditions in a school, the quality in the teaching can greatly affect academic work of students. Thus, in essence, improving the quality of teaching can improve the academic performance of students.

Inquiry is a fundamental system in the way humans can most successfully go about acquiring new knowledge (Short, 2009). Inquiry methods have also been alluded to as higher order thinking and questioning (Marzano, 2003). Teaching as inquiry involves discovery, problem solving and research aimed at improving the teaching practices (Aulls, Shore, \& Delcourt, 2008, Conner, 2015). According to a report by the Ministry of Education of New Zealand (2007), there has been an increased expectation that teachers in schools adapt and refine their teaching practices to individual school contexts in order to meet the needs of all students. This means more emphasis on teachers evaluating their own practices to improve upon the practices and enhancing their professional development.

Teaching as inquiry, even though, recognized as a hallmark of professional practice (Sachs, 1997), teachers sometimes concentrate on only how students are learning while ignoring their own professional development (Conner 2015; Fullan, 2007; Timperly \& Wiseman, 2003; Timperly \& Parr, 2004). This is more particular in places where teacher professionalism is low (Clarke \& Erickson, 2003). For instance, in African countries and places like Ghana, rarely do teachers in basic schools seek to improve their own professional standing. Again, in spite of the fact that TAI has made significant inroads in education, particularly in developed countries (Clarke \& Erickson, 2003; Conner, 2015; Darling-Hammond, Wei, Addree, Richardson, \& Orphanos, 2009, Hipkins, 2015; Kaser \& Halbert, 2014), there still remains a lot to be done to ensure that teaching as inquiry is employed by teachers. This study therefore sought to investigate teaching as inquiry and its implications for teaching and learning in the Cape Coast Metropolis. The study employed mixed methods to answer the following questions:

- What is the level of knowledge of teachers in the Cape Coast Metropolis about TAI?

- What practices of school teachers in Cape Coast Metropolis are in synchronized with TAI?

- What challenges do school teachers in the Cape Coast Metropolis face in undertaking TAI?

- What is the impact of teaching as inquiry on the outcomes of teaching and learning in the Cape Coast Metropolis?

\section{Literature Review}

Researchers have sought to identify the knowledge level of school teachers about teaching as inquiry. Ababio and Dumba (2014) empirically assessed the extent to which geography teachers adhered to the Ghana Education Service policy guidelines on the teaching of geography at the Senior High School Level in Ghana. Census survey was used to collect data from seven geography teachers because of the researchers' objective of gaining a quick insight into the problem at hand. Simple random sampling was, however, used to select 80 geography students. One of the key findings was that all the teachers had knowledge and mastery of the content areas of geography. Again, the study revealed that the geography teachers implemented to a fairly large extent the policy guidelines on teaching by employing a variety of teaching methods, though with varying emphases. However, the study showed that some students could not acquire skills in the handling of certain equipment (e.g. in surveying) either because of the non-availability of those equipment in their schools or their teachers lacked the expertise to teach them how to use those equipment even though those equipment were available. On the basis of this, the students suggested the frequent use of inquiry methods such as field work and project work. The authors recommended therefore that there should be regular in-service training for practicing geography teachers to enable them improve upon their professional competence, particularly their pedagogical skills. The implication of the findings of Ababio and Dumba (2014) is that teachers were not practicing teaching as inquiry because they did not have the expertise regarding teaching as inquiry.

Loucks-Horsley and Matsumoto (1999) also advocated after their research that coursework and professional development situations should be provided for teachers to get the opportunity to simultaneously learn and experience 
content to be taught. New Zealand's Education Office (2016) also revealed that teaching as inquiry is practiced because teachers had the skills needed for teaching as inquiry. Some other studies have indicated that teachers believed in themselves concerning their knowledge of teaching as inquiry (Byrum, Jarrell, \& Munox, 2002; McDougall, Saunders, \& Goldenberg, 2007; Oakley, 2000; \& Puchner \& Taylor, 2006). Jeanpierre (2006) carried out a study about the teaching as inquiry practices of teachers. Based on an analysis of teachers' responses to a rated closed-ended survey on their inquiry practices, which was crosschecked with open-ended qualitative responses, the teachers were found to be using several different science research skills during instruction. However, the teachers reported that the use of inquiry research skills likely occurred during guided inquiry projects with little evidence to support that they used full inquiry. The implication is that inquiry practices were not used in full.

Again, Haddock (2014) also sought to determine the difference between inquiry-based teaching strategies and student achievement. The researcher also investigated the origin of inquiry based teaching knowledge and International Baccalaureate Primary Years Programme (IBPYP) affiliation. The McGill Strategic Demands of Inquiry Questionnaire (MSDIQ) was used to determine teacher beliefs of inquiry based teaching strategies. Student achievement was measured using Florida Comprehensive Achievement Test 2.0 (FCAT 2.0) levels. Results from the MSDIQ indicated strong beliefs among participants of inquiry based teaching indicators within three domains: planning, enactment, and reflection.

In addition, Sinnema and Robinson (2007) reported on a series of empirical studies that investigated the extent to which teacher evaluation policies and procedures promote teachers' inquiry into the relationship between their teaching and their students' learning. The review showed that there was weak focus on student learning in teacher evaluation. This was revealed to be due to the lack of an inquiry stance, the compliance-driven approach taken to teacher evaluation, and the overemphasis on norms of professional collegiality. Sinnema and Robinson therefore argued for an alternative approach to teacher evaluation that promotes teachers' capacity to inquire into and strengthen the relationship between their teaching and their students' learning in order to improve teaching and learning.

Further, Gejda and LaRocco (2006) conducted a survey of 305 in-service secondary science teachers about their inquiry practices. The study found that 78 percent practiced inquiry in their classrooms once a month because they felt it benefited their students understanding of science. Also, Johnson (2006) investigated questions regarding teachers' beliefs, attitudes, and confidence with respect to practices of scientific inquiry. Pre- and post-test surveys were used to study teachers' attitudes, beliefs, and confidence regarding inquiry teaching and the impacts of this experience on teaching in order to gain a deeper understanding of how experiences play a role in teachers' attitudes and beliefs about teaching and learning. The study showed that teachers' background, experiences, and beliefs played a role in classrooms. Thus, these background characteristics influenced teachers' usage practice of teaching as inquiry.

Further, New Zealand's Education Office (2016) found that in 77\% of the classrooms in their evaluation, teaching as inquiry was highly practiced. Teachers were habitually engaging in teaching as inquiry. Teachers who were not undertaking teaching as inquiry often did engage in some of the times. The report found specifically that teachers identified the needs of students and incorporated such into their teaching plans. The teachers also reflected on their teaching methods and styles to ensure that they were beneficial to students.

As in the case of implementing any practice, school teachers face several challenges in undertaking teaching as inquiry. This has been the subject of interest among several researchers. DiBiase and McDonald (2015) sought to determine teachers' attitudes, values, and beliefs about inquiry. The participants of this study were 275 middle grade and secondary science teachers from four districts in North Carolina. Issues such as accountability, curricular demands, and administrative support were perceived by the respondents as constraints impeding teaching as inquiry. DiBiase and McDonald concluded that these are the issues that must be effectively dealt with in the professional education and professional development of all science teachers.

The study of Gejda and LaRocco (2006) on the inquiry practices of in-service secondary science teachers about their inquiry practices found that 68 percent of the teachers felt that time was the greatest obstacle in undertaking teaching as inquiry. Reiff (2002) sought to identify the reasons teachers were not using teaching as inquiry practices in the classroom. The pre-service teachers sampled for the study uniformly attributed the lack of TAI to teachers' perception of inquiry. This finding supported the view of Pintrich and DeGroot (2009). Pintrich and DeGroot posited that beliefs would ultimately prove to be the most valuable psychological construct to teacher education. The educational beliefs of prospective teachers played a pivotal role in how they interpret pedagogical knowledge, and as such any inconsistency between teachers' beliefs and methods of instruction presented to them may be responsible for the continuance of ineffectual teaching practices. 
TAI practices have implications for the school teacher. Driver (2011) investigated the understandings and challenges of teachers on TAI. A qualitative methodology was employed for this study conducted in two phases. In phase one, documentary analysis was undertaken to provide a contextual background on the expectations from official sources on the leadership activity that may promote teaching as inquiry, a culture of inquiry and the notion of schools as learning organizations. Concurrently, a purposive questionnaire provided base-line data of the prevalence of teaching as inquiry across a small geographical area within Auckland. A small scale multiple case study was undertaken in phase two, where ten semi-structured interviews took place across three research locations with school leaders and teachers to examine the understandings, practices and challenges for implementing teaching as inquiry. The findings from this study revealed that teaching as inquiry is a tool for implementing change within schools and managing change is challenging for school leaders and teachers. The findings also exposed that the school context largely determined the extent to which teaching as inquiry was understood and practiced by staff (Driver).

Several studies suggest that students learn more deeply and perform better on complex tasks if they have the opportunity to engage in more "authentic" learning-projects and activities that require them to employ subject knowledge to solve real world problems (Barron \& Darling-Hammond, 2008). Also, there is a positive impact on learning when students participate in lessons that require them to construct and organize knowledge, consider alternatives, engage in detailed research, inquiry, writing, and analysis, and to communicate effectively to audiences (Newmann, 1996). A study with about 2,100 students in 23 schools, selected from 16 states and 22 districts in USA, found significantly higher achievement on intellectually challenging performance tasks for students who experienced some kind of authentic pedagogy (Newmann, Marks, \& Gamoran, 1996). Reiff (2002) also sought to identify the reasons teachers were not using teaching as inquiry practices in the classroom. Reiff's study indicated the need to involve faculty members in developing conceptions of inquiry and ways to incorporate inquiry into different classroom settings. However, teaching as inquiry must make sense to teachers so they will use it because they genuinely desire to do so, not just because the standards say so. Ermeling (2010) also revealed that meaningful instructional changes are more likely when teachers engage in the continuous improvement of instruction through teaching as inquiry. Even though teaching as inquiry is widely accepted as a means of improving education there is still no common understanding of teaching as inquiry (Maaß \& Engeln, 2014). This implies that there is the need to carry out several studies to investigate teaching as inquiry in schools. This is with the hope that research can help make clearer the concept of teaching as inquiry.

\section{Conceptual Framework - Teaching as Inquiry Cycle}

TAI is therefore a cyclical process of different phases. The New Zealand's Ministry of Education (2011) proposed a cycle of teaching as inquiry that can be used in schools (Figure 1). The figure shows that teaching as inquiry goes through a cyclic process of different phases. Teachers' decisions should be based on a thorough understanding of their students' learning needs and a candid examination of their own practice. This is the phase of focusing inquiry. This examination is followed by inquiring into the impact of their practice on their students and by considering what additional practices might improve outcomes for their students. This is the teaching inquiry phase. After this phase, teaching and learning takes place. The next phase is the learning inquiry phase. At this phase, the teacher evaluates the result of teaching and the implications for further teaching. After the evaluation, the teacher identifies if there is something to change and then starts back at the teaching inquiry phase. If there is nothing to change, the teacher decides on the next things to learn and starts at the focusing inquiry phase. 


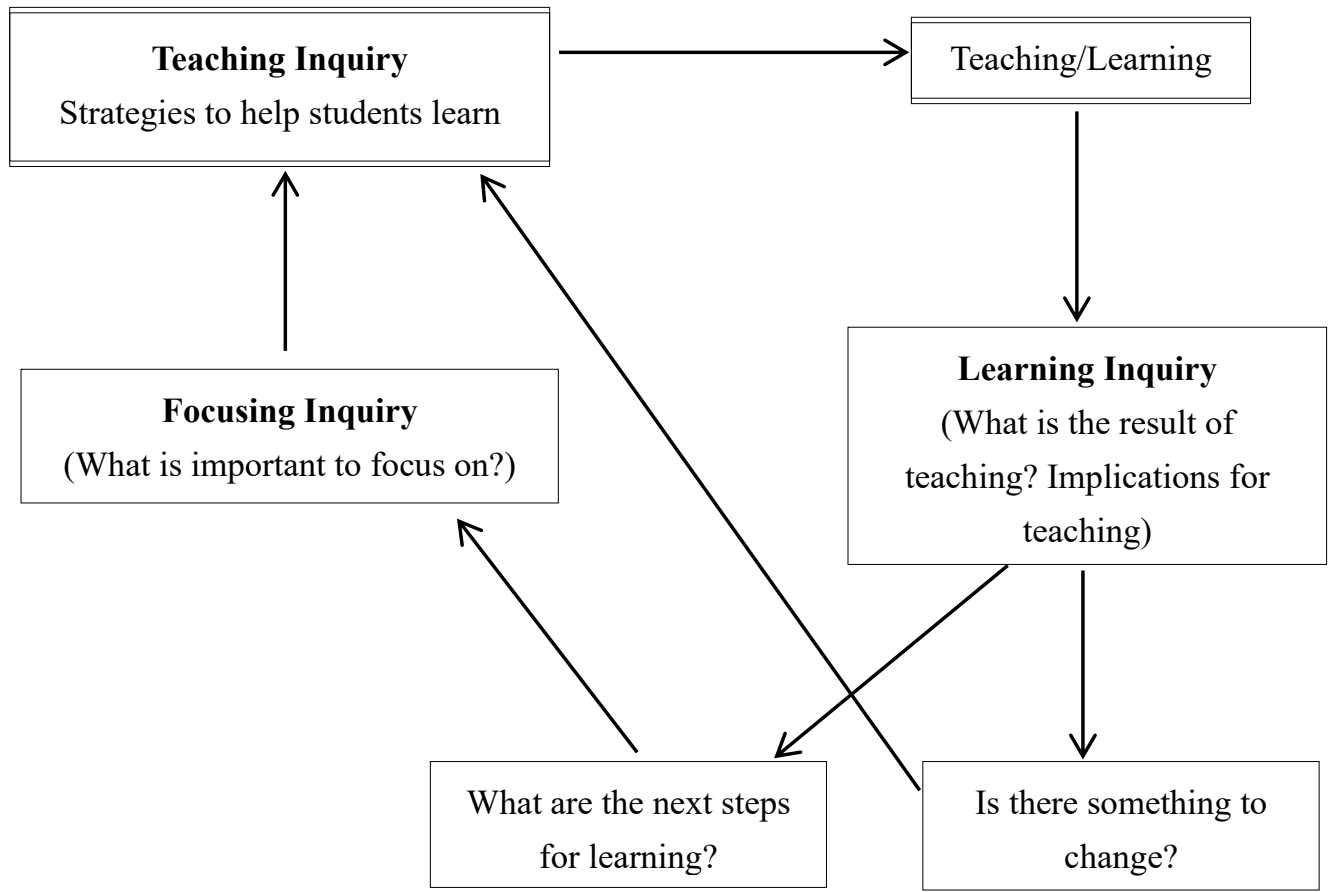

Figure 1. Teaching as Inquiry Cycle (New Zealand's Ministry of Education, 2011)

\section{Methods}

In carrying out this study, the descriptive survey research design was adopted. The descriptive survey design was used within the mixed methods approach. By adopting descriptive survey within the mixed methods model, data was collected via both quantitative and qualitative means. The assessable population for the study was made of JHS teachers in the Cape Metropolis. There were six educational circuits within the Metropolis at the time of the study. Out of this number, three circuits were randomly selected for the study. Based on statistics from the Metropolitan Education Office, the population of teachers in the three selected circuits was 272. Using Krejcie and Morgan's (1970) table for determining sample size. A sample size of 160 teachers was selected to participate in the study.

Also, nine respondents out of the sample of 160 was selected for the interview. Three teachers were selected from each circuit. Selecting nine respondents for the interview is appropriate for qualitative data (Adler \& Adler in Baker \& Edwards, 2012). Questionnaire and interview guide were adopted in collecting the data. Data for research questions one and two was analyzed using frequencies and percentages while data for research questions three and four was analyzed using means and standard deviations. The interview data was transcribed and presented by doing thematic analysis according to the research questions of the study. Where quotes are used to substantiate the survey findings, they were chosen because they were illustrative of the statements of most of the respondents

\section{Results}

In this section, the findings from the study inquiring into teachers understanding of teaching as inquiry and its implications for teaching and learning are presented in relation to the research questions that were formulated to guide the study.

\subsection{Knowledge of Teachers about Teaching as Inquiry}

Research question one was meant to identify the level of knowledge of teachers in the Cape Coast Metropolis about teaching as inquiry. Almost all the respondents $(91.3 \%)$ had heard of teaching as inquiry however, they had not attended any workshop or conference on teaching as inquiry nor acquired any professional training. When asked to explain teaching as inquiry, most of the respondents viewed teaching as inquiry as a form of probing into their teaching methods and to find ways of improving upon them. Some of the specific comments by the respondents are as follows: 
Teaching as inquiry refers to teachers investigating into their teaching methods (Respondent- JHS 2 Science teacher)

Another teacher had this definition to share:

I think teaching as inquiry involves teachers probing their own teaching so that they can teach better (Respondent-JHS 1 Mathematics teacher).

Upon further interaction, one of the teachers explained the construct as:

Reflecting, questioning and reviewing teaching methods by teachers themselves can be seen as teaching as inquiry (Respondent-JHS 3 Science teacher).

With regard to the interview data, all the respondents interviewed had heard of teaching as inquiry and heard of it during their teacher training days. However, they had not had any other form of training from workshops aside their original training. In terms of definition, the respondents also viewed teaching as inquiry as teachers evaluating their own teaching. Some of the views of the respondents interviewed included:

I think teaching as inquiry involves teachers evaluating their own teaching to find ways of improving themselves (Respondent- JHS 3 English Teacher)

In my view, teaching as inquiry is more about teachers examining their own teaching (Respondent- JHS 1 Mathematics Teacher).

\subsection{Teaching as Inquiry Practices of School Teachers}

Research question two sought to identify the teaching as inquiry practices of school teachers in the metropolis. The respondents were asked to indicate how often they engaged in some teaching as inquiry practices. The data obtained from the respondents was analyzed using frequencies and percentages and indicated in Table 1.

Table 1. Teaching as Inquiry Practices of School Teachers $(\mathrm{n}=160)$

\begin{tabular}{|c|c|c|c|c|c|c|c|}
\hline \multirow{2}{*}{ Statement } & \multicolumn{2}{|c|}{$\mathrm{VO}+\mathrm{O}$} & \multicolumn{2}{|l|}{$\mathrm{S}$} & \multicolumn{2}{|c|}{$\mathrm{R}+\mathrm{N}$} & \multirow{2}{*}{ Remarks } \\
\hline & Freq. & $\%$ & Freq & $\%$ & Freq & $\%$ & \\
\hline I reflect and question my methods of teaching & 131 & 81.9 & 17 & 10.6 & 44 & 27.5 & A practice \\
\hline $\begin{array}{l}\text { I try to find out how the content I am teaching } \\
\text { connects to the real world }\end{array}$ & 66 & 41.2 & 50 & 31.3 & 44 & 27.5 & A practice \\
\hline $\begin{array}{l}\text { I engage in research concerning the subject and } \\
\text { content I am teaching }\end{array}$ & 99 & 61.9 & 18 & 11.3 & 44 & 27.5 & A practice \\
\hline I give students the opportunity to learn on their own & 98 & 61.2 & 62 & 38.8 & - & - & A practice \\
\hline I engage in guided instruction & 98 & 61.2 & 61 & 38.1 & - & - & A practice \\
\hline $\begin{array}{l}\text { I give students the opportunity to question what is } \\
\text { being taught }\end{array}$ & 82 & 51.2 & 78 & 48.8 & - & - & A practice \\
\hline I encourage collaboration & 99 & 61.9 & 29 & 18.1 & - & - & A practice \\
\hline $\begin{array}{l}\text { I find out the academic needs of my students before } \\
\text { planning my instruction }\end{array}$ & 124 & 77.4 & 18 & 11.3 & 18 & 11.3 & A practice \\
\hline I encourage risk taking in the classroom & 16 & 10.0 & 83 & 51.9 & 61 & 38.1 & Not a practice \\
\hline I engage in projects with my students & 113 & 70.6 & 47 & 29.4 & - & - & A practice \\
\hline
\end{tabular}

Key-VO-Very Often, O-Often, S-Sometimes, R-Rarely, N-Never.

Table 1 shows how often teachers engaged in teaching as inquiry practices. It can be seen from the table that majority of the respondents often reflected and questioned their methods of teaching ( $n=131,81.9 \%$ ), identified the academic needs of students before planning instruction $(\mathrm{n}=124,77.4 \%)$ and engaged in projects with their students $(\mathrm{n}=113,70.6 \%)$. Other significant practices of the respondents included engaging in research concerning the subject and content they were teaching $(\mathrm{n}=99,62 \%)$ and encouraging collaboration in the classroom $(\mathrm{n}=99,62 \%)$.

The respondents who were interviewed indicated that they questioned and reflected their teaching often, they evaluated their teaching to see whether their teaching was effective and researching into the subjects they taught. One teacher indicated:

"Most of the time, I try to find out if my style and method of teaching is working. As a teacher I ensure that I reflect on my teaching strategies and methods to see how they have impact on my students. These 
reflections are to help me match my teaching skills to the learning outcomes" (Respondent-JHS 1 Mathematics Teacher).

Another also commented:

"I often reflect on my teaching and question my own methods to find out the best way to teach" (Respondent-JHS 2 Science Teacher)

Overall, it can be inferred that most of the respondents often engaged in practices that can be viewed as teaching as inquiry.

\subsection{Challenges Teachers Face in Undertaking Teaching as Inquiry}

Research question three was meant to identify the challenges school teachers faced in undertaking teaching as inquiry. The teachers indicated the extent to which they faced certain challenges in undertaken teaching as inquiry. Their responses were coded and ranked using a scale of 1 (strongly disagree) to 4 (strongly agree). The data obtained from the respondents was analyzed using mean and standard deviation. The results are presented in Table 2.

Table 2. Challenges of Teaching as Inquiry $(n=160)$

\begin{tabular}{llll}
\hline \multirow{2}{*}{ Statement } & \multicolumn{2}{c}{$\mathrm{TV}=2.50$} & \multirow{2}{*}{ Remarks } \\
\hline The curriculum does not support teaching as inquiry & $\mathrm{M}$ & $\mathrm{SD}$ & \\
The class size in our classrooms does not support teaching as inquiry & 2.44 & 0.66 & Not a challenge \\
Time limitation does not encourage teaching as inquiry & 3.43 & 0.92 & Not a challenge \\
Lack of administrative support does not encourage teaching as inquiry & 2.59 & 0.46 & A challenge \\
Negative perception of teachers about inquiry & 3.25 & 0.75 & A challenge \\
Lack of motivation to engage in inquiry & 3.13 & 0.82 & A challenge \\
Lack or inadequate resources in undertaking teaching as inquiry & 2.21 & 0.75 & Not a challenge \\
\hline
\end{tabular}

Key-M=Mean, $\mathrm{SD}=$ Standard Deviation, $\mathrm{TV}=$ Test Value

It can be seen from Table 2 that the statement 'time limitation does not encourage teaching as inquiry' recorded the highest mean of 3.69 and a standard deviation of 0.46 . This means that majority of the respondents agreed that time limitation was a challenge in undertaking teaching as inquiry. The other significant challenges indicated by most of the respondents included 'negative perception of teachers about inquiry $(\mathrm{M}=3.25, \mathrm{SD}=0.75)$ and 'lack of motivation to engage in inquiry $(\mathrm{M}=3.13, \mathrm{SD}=0.82)$. Therefore, the main challenges encountered in undertaking teaching as inquiry among teachers in the Cape Coast Metropolis were time limitations, negative perceptions and lack of motivation.

These results were similar to what was indicated by the respondents who were interviewed. They indicated that undertaking teaching as inquiry took a lot of time and as such was challenging. They also viewed teaching as inquiry as challenging because there was not much support in undertaking teaching as inquiry. One of the teachers had this to share:

I think a lot of time is required to engage in teaching as inquiry. This makes it a challenging exercise. We the teachers do not have enough time to explore the inquiry method. Teaching as inquiry is involving and therefore require enough time. Fully engaging in Teaching as inquiry virtually means that, we will not have time for other equally important academic activities (Respondent-JHS 2 Mathematics Teacher)

Another also indicated:

Researching and evaluating your own subject or teaching method can be a difficult task that without support can be demotivating (Respondents-JHS 3 Science Teacher)

\subsection{Impact of Teaching as Inquiry on Teaching and Learning Outcomes}

Research question four sought to find out the impact of teaching as inquiry on teaching and learning. Similar to research question 3, responses were coded using the four-point Likert scale and data obtained was analyzed using mean and standard deviation. The results are presented in Table 3. 
Table 3. Impact of Teaching as Inquiry $(\mathrm{n}=160)$

\begin{tabular}{llll}
\hline \multirow{2}{*}{ Statement } & \multicolumn{2}{l}{ Test Value=2.50 } & Remarks \\
\cline { 2 - 3 } & Mean & Std. Dev. & \\
\hline Teaching as inquiry can improve the teaching of teachers & 3.41 & 0.66 & High impact \\
Teaching as inquiry can improve academic work of students & 2.69 & 0.46 & Moderate impact \\
Teaching as inquiry helps teachers develop their research abilities & 2.84 & 0.87 & Moderate impact \\
Teaching as inquiry is a waste of time and does not help teaching and learning & 1.43 & 0.49 & No impact \\
Teaching as inquiry improve the capacity of teachers to learn and relearn & 3.13 & 0.71 & High impact \\
Average Mean/Std.D $>2.50$ & 2.70 & 0.64 & \\
\hline
\end{tabular}

The mean scores as can be seen in Table 3, the statement 'teaching as inquiry can improve the teaching of teachers' recorded the highest mean of 3.41 and a standard deviation of 0.66 . Other impacts identified by most of the respondents were "teaching as inquiry improve the capacity of teachers to learn and relearn $(\mathrm{M}=3.13>\mathrm{TV}, \mathrm{SD}=0.71)$, 'teaching as inquiry helps teachers develop their research abilities ( $\mathrm{M}=2.84>\mathrm{TV}, \mathrm{SD}=0.87)$ ' and 'teaching as inquiry can improve academic work of students $(\mathrm{M}=2.69>\mathrm{TV}, \mathrm{SD}=0.46)$. Thus, it can be inferred that teaching as inquiry can improve teachers' teaching and research capacities thereby enhancing students' academic achievement.

The interviewees also revealed that teaching as inquiry has the potency of improving the teaching of teachers. Again, by improving the teaching practices of teachers, students' academic work can be improved. Some of the main statements of the respondents are:

As teachers engage in teaching as inquiry, they are likely to identify the best and appropriate methods to teach specific subjects and topics (Respondent-JHS 2 Mathematics Teacher)

Teaching as inquiry can help teachers teach well and therefore improve the academic work of students (Respondent-JHS 3 English Teacher).

\section{Discussion and Implication}

The study revealed that majority of the respondents had heard of teaching as inquiry and that most of them had acquired training on teaching as inquiry in their years of schooling. However, majority of the respondents had not attended any workshop or conference on teaching as inquiry. The study again showed that most of the respondents viewed teaching as inquiry as a means by which teachers research and evaluate into their own teaching. Overall, it appeared from the results that the teachers were knowledgeable about teaching as inquiry. This was a good indication. However, not attending workshops and conferences on teaching as inquiry was not a good sign. This could mean that the authorities in charge of education in the Metropolis did not put in much effort in training teachers professionally on teaching as inquiry. The findings that teachers had knowledge about teaching as inquiry confirmed the claims of New Zealand's Education Office (2016) that teaching as inquiry is practiced because teachers had the skills needed for teaching as inquiry. Some other studies have indicated that teachers believed in themselves concerning their knowledge of teaching as inquiry (Byrum, Jarrell, \& Munox, 2002; McDougall et al, 2007; Oakley, 2000; \& Puchner $\&$ Taylor, 2006). The finding that teachers lack professional training on TAI aligns with the assertion by Ababio and Dumba (2014) that teachers need regular in-service training TAI. As a professional activity, there is the need for some professional competence which can only be acquired through professional training. Even though teachers have knowledge concerning TAI, there is still the need to provide some additional professional training for teachers to maximize its usage. This creates a sense of responsibility among teachers and school authorities.

In terms of the teaching as inquiry practices of teachers, the study found that teachers engaged in TAI practices such as reflecting and questioning their methods of teaching, identifying the academic needs of students before planning instruction and engaging in projects with their students. Most of the respondents also engaged in research concerning the subject and content they were teaching. Overall, it can be realized that most of the respondents often engaged in practices that can be viewed as teaching as inquiry. These findings are good indicators for teacher improvement in the Cape Coast Metropolis. These findings are in line with the findings of New Zealand's Education Office (2016) that in $77 \%$ of the classrooms in their evaluation, teaching as inquiry was highly practiced. Teachers were habitually engaging in TAI. Teachers who were not undertaking teaching as inquiry often did engage in some of the times. Their study found specifically that teachers identified the needs of students and incorporated such into their teaching plans. The teachers also reflected on their teaching methods and styles to ensure that they were beneficial to students. All these were confirmed in the current study. Similar to this, Gejda and LaRocco (2006) conducted a survey of 305 in-service secondary science teachers about TAI. The study found that 78 percent of the teachers practiced TAI in their 
classrooms once a month because they felt it benefited their students understanding of science.

In a similar vein, Jeanpierre (2006) found that teachers engaged in research concerning their teaching. However, this was not done often. Haddock (2014) also found that teachers engaged in planning and reflection concerning their teaching. They did this with the aim of finding ways to improve their teaching. The teachers in the current study were also seeking for means to improve the academic work of their students. As a result, evaluating, questioning and researching into the best teaching practices were ideal for them.

Regarding the challenges faced in engaging in TAI, the study found that the main challenges were time limitations, negative perceptions and lack of motivation. The academic system in Ghana is such that there is limited time to seek to improve teaching. Once school starts, teachers race time to ensure that the curriculum is completed before examination starts. In this sense, teachers reflecting and researching into their teaching methods is seen by most teachers as a time consuming activity. As a result, time presented a challenge to effectively engaging in teaching as inquiry. Again, there are occasions where trying to find the best means to improve teaching may make teachers feel like they are not doing their best. Thus, the negative perceptions about teaching as inquiry might make it challenging for teachers to engage in TAI. Further, there is no encouragement to engage in TAI. Teachers therefore do not feel motivated enough to research and assess their teaching. Education authorities are mostly just concerned about teachers teaching and not about improving the teaching of teachers. This has a connection to the finding of the study that there were no professional workshops and conferences on teaching as inquiry. As a result, teachers do not have the motivation to engage in TAI.

These results corroborate the findings of Gejda and LaRocco (2006) on the inquiry practices of in-service secondary science teachers. The study found that 68 percent of the teachers felt that time availability was the greatest obstacle in engaging in TAI. Again, the findings support the findings of DiBiase and McDonald (2015) who sought to determine teachers' attitudes, values, and beliefs about inquiry. Their study found that issues such as accountability, curricular demands, and administrative support were perceived by the respondents as constraints impeding TAI. In addition, Reiff (2002) sought to identify the reasons teachers were not using teaching as inquiry practices in the classroom. It was found that the pre-service teachers sampled for the study uniformly attributed the lack of teaching as inquiry to teachers' perception of inquiry. This was confirmed in the current study. The educational beliefs of teachers play a pivotal role in how they interpret pedagogical knowledge, and as such any inconsistency between teachers' beliefs and methods of instruction presented to them may be responsible for the continuance of ineffectual teaching practices (Anderson \& Piazza, 1996).

TAI, since identified as an important part of teaching, can affect the outcomes of teaching and learning in various ways. The study found that TAI can improve the teaching of teachers, improve the capacity of teachers to learn and relearn, helps teachers develop their research abilities, and ultimately improve the academic work of students. As teachers research and reflect on their own teaching, their teaching methods are likely to improve. Again, teachers get the opportunity to learn new things they might not have known before engaging in TAI. Teachers can also relearn some of the things they knew already. Aside these, teachers get to develop their research abilities as they engage in TAI. All these aim to ultimately improve the academic work of students. When teaching methods improve and teachers identify the needs of students before teaching, they are more likely to teach the right content using the right methods. The findings are in line with the work of Ermeling (2010) that meaningful instructional changes are more likely when teachers engage in the continuous improvement of instruction through TAI. In a similar vein, Driver (2011) investigated the understandings and challenges of teachers on teaching as inquiry and found that teaching as inquiry is a tool for implementing change within schools. These changes are implemented in a positive light aimed at improving teaching and learning outcomes in schools. Also, there is a positive impact on learning when teachers engage in detailed research, inquiry, writing, and analysis, and to communicate effectively to students. A study of more than 2,100 students in 23 schools found significantly higher achievement on intellectually challenging performance tasks for students who experienced some kind of "authentic pedagogy" from teachers (Newmann, Marks, \& Gamoran, 1995). The findings of the current study are consistent with previous studies about teachers enacting inquiry into their teaching. The use of authentic pedagogy is possible through teaching as inquiry and has a greater impact on students' achievement.

\section{Conclusions and Recommendations}

All over the world there is a moral imperative to raise the achievement of student who are not achieving well for whatever reason. As part of this agenda, it is important for teachers to connect with the worlds (communities and cultures) to which the students belong (Conner, 2015). There is a clear understanding of the impact of TAI on 
academic successes on the part of both teachers and students. However, it takes time, perseverance, coaching, sharing ad some risk taking to develop the skills to be able to seek the information needed about learners, and to align this information with the goals and changes to pedagogy.

The teachers in the study were more enthusiastic and had gain more interest in their work as a result of TAI. The teachers have become more curious about the performance of their students and are ready and willing to find out more information about them to inform their planning and support of students' learning. While there's the need of continuous improvement for the benefit of students as part of what teachers do as professionals there is the need to consider how the context/environment can support teachers to undertake TAI more effectively. Teachers need to be supported to develop specific subject related and/or design interventions for their learners. The benefits of these changes will be seen through student participation and achievement data.

In this study, teachers engage in teaching as inquiry, especially in terms of reflecting and questioning their methods of teaching, identifying the academic needs of students before planning instruction and researching concerning the subject and content they were teaching. Improving the capacity of teachers to learn and relearn, helping teachers develop their research abilities, and improving the academic work of students are results of teaching as inquiry. It is therefore recommended that Cape Coast Metropolitan Education Office should organize intermittent workshops and training for teachers on teaching as inquiry. This will help teachers to build specific skills and refinements for reflection and action and planning strategies to support learners to learn specific things (content or skills) that teachers can specifically monitor in terms of student outcomes. Research shows that it is often not until teachers work with data in relation to their students' outcomes, that they realize they have or have not made a difference. That is, teaching as inquiry needs to be based on students' outcomes "data" in various forms to make it evidential. All good teachers reflect but it is what they reflect on, and what changes they make and how they monitor outcomes that truly shift reflection to inquiry.

\section{References}

Ababio, B. T., \& Dumba, H. (2014). Assessment of the policy guidelines for the teaching and learning of geography at the senior high school level in Ghana. Review of International Geographical Education Online (RIGEO), 4(1), 23- 40 .

Akhihiero, E. T. (2011). Effect of inadequate infrastructural facilities on academic performance of students of Oredo Local Government Area of Edo State. The Nigerian Academic Forum, 20(1), 1-6.

Anderson, D., \& Piazza, J. (1996). Changing beliefs: Teaching and learning mathematics in constructivist pre-service classrooms. Action in Teacher Education, 2, 51-62. https://doi.org/10.1080/01626620.1996.10462833

Aulls, M. W., Shore, B. M., \& Delcourt, M. A. (2008). Inquiry in education: The conceptual foundations for research as a curricular imperative (Vol. 1). New York, NY: Routledge.

Barron, B., \& Darling-Hammond, L. (2008). Teaching for meaningful learning: A review of research on inquiry-based and cooperative learning. Book excerpt. George Lucas Educational Foundation.

Baker, S. E., \& Edwards, R. (2012). How many qualitative interviews is enough? Expert voices and early career reflections on sampling and cases in qualitative research. UK: National Centre for Research Methods.

Benade, L. (2015). Teaching as inquiry: Well intentioned, but fundamentally flawed. New Zealand Journal of Educational Studies, 50, 107-120. https://doi.org/10.1007/s40841-015-0005-0

Biesta, G. J. J., \& Burbules, N. C. (2003). Pragmatism and educational research. Lanham, MD: Rowman \& Littlefield.

Brock, P. (2000). Standards of professional practice for accomplished teaching in Australia classrooms: A national discussion paper. Sydney, Australia: Australian College of Education, Australian Curriculum Studies Association and Australian Association for Research in Education.

Byrum, J. L., Jarrell, R., \& Munox, M. (2002). The perception of teachers on the impact of the lesson study initiative. Louisville, KY: Jefferson County Public Schools.

Clarke, A., \& Erickson, G. (2003). Teacher inquiry: A defining feature of professional practice. Retrieved from blogs.ubc.ca/stevemcg/files/2014/.../Clarke-Erickson-Chap-1.-Pg-1-6-for-Sept-25th.p

Conner, L. (2015). Teaching as inquiry with a focus on priority learners. Wellington, NZ: New Zealand Council of Educational Research.

Cuttance, P. (2000). The impact of teaching on student learning. Australian College of Education yearbook 2000. 
Canberra: Australian College of Education.

Darling-Hammond, L., Wei, R. C., Andree, A., Richardson, N., \& Orphanos, S. (2009). Professional learning in the learning profession. Washington, DC: National Staff Development Council.

DiBiase, W., \& McDonald, J. R. (2015). Science teacher attitudes toward inquiry-based teaching and learning. The Clearing House: A Journal of Educational Strategies, Issues and Ideas, 88(2), 29-38. https://doi.org/10.1080/00098655.2014.987717

Driver, J. (2011). Teaching as inquiry: Understandings and challenges towards a professional way of being. Master's Thesis, Unitec Institute of Technology, Auckland.

Ermeling, B. A. (2010). Tracing the effects of teacher inquiry on classroom practice. Teaching and teacher education, 26(3), 377-388. https://doi.org/10.1016/j.tate.2009.02.019

Fullan, M. (1993). Change forces: Probing the depths of educational reform. London: Falmer Press.

Gejda, L., \& LaRocco, D. (2006). Inquiry-based instruction in secondary science classrooms: A survey of teacher practice. Paper presented at the 37th Annual Northeast Educational Research Association Conference, Kerhonkson, New York.

Haddock, L. C. (2014). A comparison of teachers' beliefs of the use of inquiry teaching, origin of knowledge of inquiry teaching, and student achievement between International Baccalaureate and Non-International Baccalaureate primary years programme schools. Unpublished doctoral dissertation, College of Education and Human Performance, University of Central Florida, Orlando, Florida.

Hattie, J., \& Marsh, H. W. (1996). The relationship between research and teaching: A meta-analysis. Review of Educational Research, 66(4), 507-542. https://doi.org/10.3102/00346543066004507

Jeanpierre, B. (2006). What teachers report about their inquiry practices? Journal of Elementary Science Education, 18(1), 57-68. https://doi.org/10.1007/BF03170654

Johnson, C. (2006). Effective professional development and change in practice: Barriers science teachers encounter and implications for reform. School Science and Mathematics, $106(3), \quad 150$. https://doi.org/10.1111/j.1949-8594.2006.tb18172.x

Jones, P. (2001). Are educated workers really more productive? Journal of Development Economics, 64, 67-79. https://doi.org/10.1016/S0304-3878(00)00124-3

Kaser, L., \& Halbert, J. (2014). Creating and sustaining inquiry spaces for teacher learning and system transformation. European Journal of Education, 49(2), 206-217. https://doi.org/10.1111/ejed.12079

Krejcie, R. V., \& Morgan, D. W. (1970). Table for determining sample size from a given population. Educational and Psychological Measurement, 30(3), 607-610. https://doi.org/10.1177/001316447003000308

Marzano, R. J. (2003). What works in schools: Translating research into action. Alexandria, VA: Association for Supervision and Curriculum Development.

McDougall, D., Saunders, B., \& Goldenberg, C. (2007). Inside the black box of school reform: explaining the how and why of change at Getting Results schools. International Journal of Disability, Development and Education, 54, 51-89. https://doi.org/10.1080/10349120601149755

Ministry of Education of New Zealand. (2007). The New Zealand curriculum. Wellington: Learning Media.

Newmann, F. M. (1996). Authentic achievement: Restructuring schools for intellectual quality. San Francisco, CA: Jossey-Bass.

Newmann, F. M., Marks, H. M., \& Gamoran, A. (1995). Authentic pedagogy: Standards that boost student performance. Issues in Restructuring Schools, 8, 1-4.

New Zealand's Education Office (2016). Leading from the Middle: Educational Leadership for Middle and Senior Leaders. Wellington: Learning Media Limited.

Nwike, M., \& Onyejegbu, C. (2013). Effects of use of instructional materials on students' cognitive achievement in agricultural science. Journal of Education and Social Research, 3(5). https://doi.org/10.5901/jesr.2013.v3n5p103

Oakley, J. A. (2000, April). Voyage of discovery: what happens when in-service teachers explore teaching for understanding through collaborative investigation? New Orleans: Paper presented at the Annual Meeting of the American Educational Research Association. 
Pintrich, P. R., \& DeGroot, E. (2009). Quantitative and qualitative perspectives on student motivational beliefs and self-regulated learning. In Annual Meeting of the American Educational Research Association, Boston, MA (Vol. 128).

Puchner, L. D., \& Taylor, A. R. (2006). Lesson study, collaboration and teacher efficacy: Stories from two school-based math lesson study groups. Teaching and Teacher Education, 22(7), 922-934. https://doi.org/10.1016/j.tate.2006.04.011

Reiff, R. (2002). If inquiry is so great, why isn't everyone doing it? Proceedings of the Annual International Conference of the Association of the Education of Teachers in Science, Charlotte, North Carolina.

Reynolds, D., Creemers, B., Stringfield, S., Teddlie, C., \& Schafer, G. (2002). World class schools: International perspectives on school effectiveness. London: Routledge.

Sachs, J. (1997). Reclaiming the agenda of teacher professionalism: An Australian experience. Journal of Education for Teaching, 23, 263-275. https://doi.org/10.1080/02607479720006

Short, K. G. (2009). Inquiry as a stance on curriculum. In S. Davidson, \& S. Carber (Eds.), Taking the PYP forward: The future of the IB primary years Programme (pp. 11-26). Great Britain: John Catt Educational Ltd.

Sinnema, C. E. L., \& Robinson, V. M. J. (2007). The leadership of teaching and learning: Implications for teacher evaluation. Leadership and Policy in Schools, 6(4), 319-343. https://doi.org/10.1080/15700760701431603

Timperley, H., \& Parr, J. M. (2004). Using evidence in teaching practice: Implications for professional learning. Auckland: Hodder Moa Beckett.

Timperley, H., \& Wiseman, J. (2003). The sustainability of professional development. Wellington: Ministry of Education. 